終りに臨み，本実娩に御協力頂いた三共株式会社田無工場長吉留涉氏ならびに御尽力を仰いた諸兄に深謝致し ます（本報告の要旨は昭和 30 年 4 月の日本䐎芸化学会大会に拈いて発表した.）

$$
\begin{gathered}
\text { エンシレージの化学的成分と品質に琞する研究 }(2)^{*} \\
\text { 一般成分と品質について } \\
\text { 須 藤 浩 (岡山大学澧学部) } \\
\text { 昭和 } 32 \text { 年 } 6 \text { 月 } 14 \text { 日受理 }
\end{gathered}
$$

\title{
I. 緒雫
}

著者はさきにエンシレージの酸含量と品質について報告したが(1), 本報では一般分析結果を述べる、分析法 は常法(2)によった， $\mathrm{pH}$ の测定法は前報(1) と同じである. 材料は主として全国より集めたもので，酸を定量した 試料を含み，その後のものをも2〜3 追加した．末た特殊なものは研究室にて小規模に製造したむのをも併せて 示した。統計的処理 ${ }^{(3 \sim 5)}$ は，主として全国よりの試料中，茥葉類について行った。

\begin{tabular}{|c|c|c|c|c|c|c|c|c|c|c|c|c|c|c|c|}
\hline No. & 避地 & 水分 & $\begin{array}{l}\text { 粗蛋 } \\
\text { 色望 }\end{array}$ & $\begin{array}{l}\text { 粗脂 } \\
\text { 肪 }\end{array}$ & 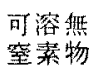 & $\begin{array}{l}\text { 粗䋊 } \\
\text { 維 }\end{array}$ & $\begin{array}{l}\text { 粗灰 } \\
\text { 分 }\end{array}$ & $\mathrm{pH}$ & 点 & $\begin{array}{l}\text { 等 } \\
\text { 級 }\end{array}$ & +10 & 埋敬量 & $\begin{array}{l}\text { 沈下 } \\
\text { 染 }\end{array}$ & 埋藏時 & 備 \\
\hline 19 & 北海道 & $\begin{array}{r}\% \\
82.71\end{array}$ & $\begin{array}{r}\% \\
1.23\end{array}$ & $\begin{array}{r}\% \\
0.12\end{array}$ & $8.93^{\%}$ & $\begin{array}{r}\% \\
5.54\end{array}$ & $\begin{array}{r}\% \\
1.47\end{array}$ & 4.6 & 21 & 可 & $\begin{array}{r}\text { 尺 } \\
12 \times 24\end{array}$ & 11,000 & 20 & $\begin{array}{c}\text { 月日 } \\
10.13\end{array}$ & \\
\hline 29 & 11 & 82.04 & .57 & 0.80 & 8.80 & 5.57 & 1.22 & 3.9 & 37 & 優 & $18 \times 33$ & 5,000 & 18 & 9.24 & 半地下式 \\
\hline 18 & 岩手 & 78.44 & .19 & 0.45 & 14.96 & 3.53 & 1.43 & 3.9 & 37 & & 18 & 53 & 10 & 10. 7 & \\
\hline 35 & "I & 87.70 & 91 & 0.34 & 6.28 & 3.92 & 0.85 & 4.1 & 38 & $" \prime$ & 10 & & 12 & 9. 3 & 地 上式 \\
\hline 6 & 曲形 & 74.30 & 27 & .74 & 15.62 & 6.44 & .63 & 3.6 & 34 & $" \prime$ & & & 25 & 10. 4 & \\
\hline 90 & "I & 81.81 & 1.13 & 0.61 & 10.07 & 4.97 & 1. 41 & 3.7 & 35 & 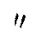 & & & & . & \\
\hline 7 & $"$ & 81.79 & 78 & 0.46 & 8.82 & 5.40 & .75 & 3.6 & 34 & " & $6 \times 12$ & 3,200 & 20 & $\begin{array}{l}8.7 \\
9.7\end{array}$ & 2 回に埋藏 \\
\hline 15 & "l & 82.27 & 20 & 48 & 8. 44 & 5.67 & 4 & 8 & 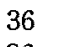 & 7 & & 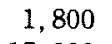 & & 9.27 & \\
\hline $20 a$ & 群 馬 & 85.83 & 1.33 & 0.33 & 7.77 & 3.54 & .20 & 4.0 & 36 & $" \prime$ & 32 & 15,000 & 10 & 9.20 & 半地下武 \\
\hline $20 \mathrm{e}$ & " & 81.85 & 0 & 0.25 & 10.32 & 4.29 & 8 & 4.1 & 35 & 柢 & 32 & 100 & 10 & & \\
\hline 58 & $\prime \prime$ & 80.66 & 1 & 0.50 & 7.71 & 6.70 & 03 & 4.9 & 0 & 少 & & 0 & 21 & 9. 3 & 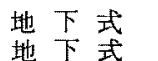 \\
\hline 23 & 東 宗 & 72.08 & 2.99 & 0.38 & 4.67 & 8.22 & 1. 66 & 3.8 & 35 & 仳 & 7 & 3,500 & 23 & 9.29 & $\begin{array}{r}\text { 菲塩添加 } \\
37.5 \mathrm{~kg}\end{array}$ \\
\hline 61 & 潟 & 18 & 61 & 0.57 & 9.83 & 6.05 & .76 & 4.1 & 39 & "1 & & & 24 & 11. 8 & \\
\hline 56 & 岥 & 1 & 1 & 0.35 & 12.50 & 6.39 & .77 & 0 & 35 & $" 1$ & 12 & 1,200 & & 10. 9 & 地下式 \\
\hline 77 & 山梨 & 72.84 & 2 & 0.70 & 14.32 & 8.16 & .88 & 3.8 & 35 & " & 4.5 & 1,200 & 15 & 11.25 & 半地下式 \\
\hline 66 & 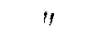 & 74.96 & 1.4 & 0.38 & 14.42 & 5.78 & .00 & 3.9 & 3 & $n$ & & 700 & 20 & 10. 2 & \\
\hline 84 & 野 & 87.81 & 1.66 & 0.39 & 4.66 & 3.70 & .78 & 4.2 & 33 & "l & & 5,600 & 13 & 8.27 & 半地下式 \\
\hline 59 & 京 都 & 71.31 & 38 & 0.59 & 12.13 & 11.19 & 40 & 3.9 & 37 & " & & 4,500 & 19 & 9.15 & $" \prime$ \\
\hline 17 & 奈 鼠 & 82.13 & & 0.45 & 9.56 & 3.70 & 2.81 & 4.0 & 38 & $" \prime$ & $6.1 \times 14$ & & 24 & 8.31 & 地下式 \\
\hline $17_{2}$ & " & 81.14 & & 0.32 & 8.19 & 6.07 & .07 & & 26 & 艮 & & & 24 & 8.28 & \\
\hline 21 & & 73.67 & & 0.46 & 14.38 & 8.19 & 2.35 & 3.9 & 34 & 砅 & & 1,500 & 27 & 10. 9 & 地下式 \\
\hline 48 & 阔 11 & 70.97 & & 0.80 & 14.36 & 9. 48 & 1.43 & 3.7 & 29 & 良 & & & & & 廃雍量なし \\
\hline 11 & 鹿罗鼻 & 84.77 & 0.94 & 0.43 & 5.27 & 6.04 & .55 & 4.6 & 4 & 少 & & 200 & 26 & 10.28角 & 型半地下式 \\
\hline 16 & $" 1$ & 88.81 & 1.60 & 0.45 & 2.90 & 4.66 & 1.58 & 4.7 & 1 & $" 1$ & 5.8 & 1,500 & 25 & 10.15 & 地上式 \\
\hline 60 & $" \prime$ & 81.51 & 1.31 & 0.68 & 9.79 & 4.58 & 2.13 & 4.1 & 36 & 傁 & & 1,200 & 21 & & \\
\hline 22 & 宮 崎 & 79.30 & & 0.71 & 8.03 & 8.94 & 1.66 & 3. 6 & 34 & $" 1$ & 9.5 & 800 & 15 & $10 \sim 13$ & 地下式 \\
\hline 12 & "' & 75.13 & 1.46 & 0.68 & 15.92 & 5.43 & 1.38 & 3.6 & 32 & 良 & $12 \times 24$ & 5,000 & 21 & 8. 3 & 地上 \\
\hline 39 & 侁 賀 & 80.07 & 1.35 & 0.27 & 10.36 & 6.37 & 1.58 & 4.8 & 11 & 中 & 20 & & & 10. 1 & \\
\hline 118 & 距胃島 & 88.21 & 1.22 & 0.66 & 3.86 & 4. 43 & 1.62 & 4.7 & 0 & 少 & & & & & \\
\hline
\end{tabular}

\section{II. 実験結果及び考察}

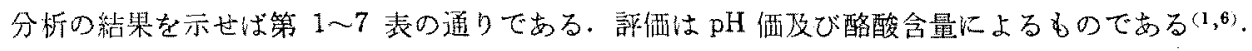

第1表 青刚トウモロコシェンシレージ（多少他の草を含むものもある）

* Studies on the Chemical Composition and the Quality of Silage. Part II. On the Nutrient Content and the Quality.

By Hiroshi SUTOH (Laboratory of Animal Feeding, Faculty of Agricultre, Okayama University, Japan) 
第 2 表 サッマイモッルエンシレージ

No. 産地 水分 粗蛋 粗脂可溶無粗織粗灰 $\mathrm{pH}$ 点等

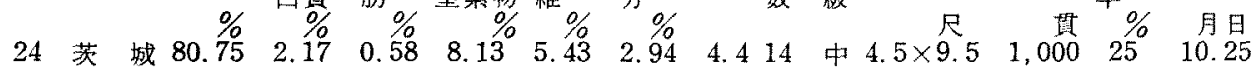

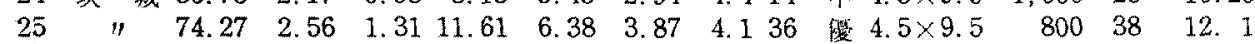

$\begin{array}{llllllllllllllll}37 & \prime \prime & 74.55 & 2.28 & 0.99 & 13.55 & 5.88 & 2.75 & 4.233 & \prime \prime & 5 \times 8 & 400 & 38 & 11.7\end{array}$

$\begin{array}{lllllllllll}50 & \text { " } & 78.93 & 2.56 & 0.89 & 5.57 & 7.83 & 4.22 & 4.8 & 2 & \text { 少 }\end{array}$

11. 細切度 $20 \mathrm{~cm}$ 以上

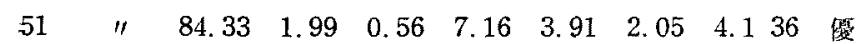

$\begin{array}{llllllllllllll}52 & 77.22 & 2.50 & 0.71 & 11.45 & 5.13 & 2.99 & 4.2 & 31 & \text { 良 } & 6 \times 15 & 2.000 & 13 & 10.24\end{array}$

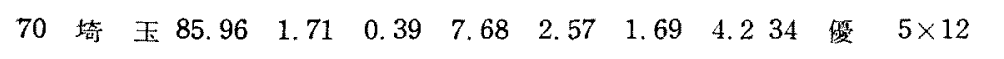

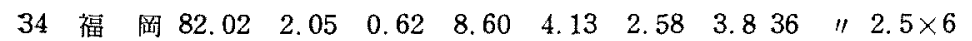

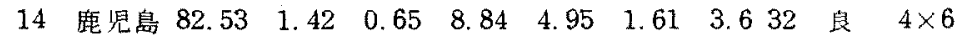

$\begin{array}{llllllllllll}30 & \text { " } & 83.23 & 1.74 & 0.59 & 8.27 & 4.58 & 1.59 & 3.836 & \text { 優 } & 5.5 \times 10\end{array}$

$\begin{array}{llllllllllll}36 & \prime & 71.12 & 3.41 & 1.12 & 13.32 & 6.50 & 4.53 & 4.1 & 38 & \prime \prime & 5.8 \times 13\end{array}$

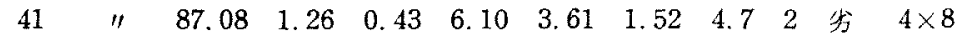

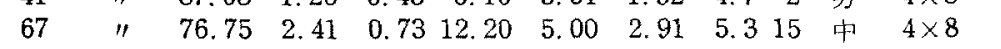

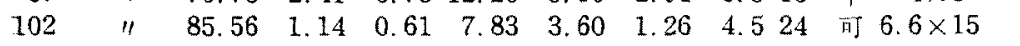

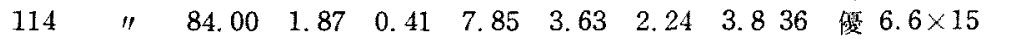

115

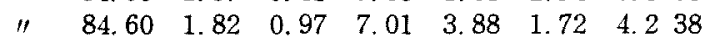

$\begin{array}{lllllllllll}\text { " } & 81.65 & 1.99 & 0.75 & 8.93 & 4.86 & 1.82 & 4.2 & 31 & \text { 良 }\end{array}$

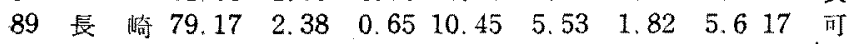

44 熊 $\quad \begin{array}{llllllllll}85.71 & 1.46 & 0.41 & 5.23 & 4.61 & 2.58 & 4.5 & 10 & \text { 中 }\end{array}$

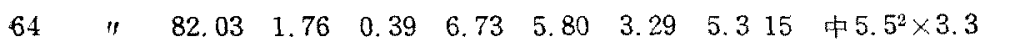

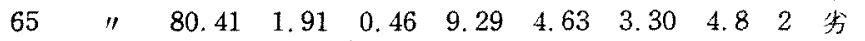

$\begin{array}{rrrc}500 & 21 & 11.10 & \text { 地下式 } \\ 120 & 32 & 11.2 & \text { 半地下式 } \\ 400 & 26 & 11.5 & \text { " } \\ & 18 & 11.7 & \\ & 21 & 11.11 & \\ 800 & 28 & 10.15 & \\ 1,500 & 10 & 11.29 & \text { 半地下式 } \\ 1,500 & 33 & 11.7 & \\ 1,500 & 11 & 11.17 & \end{array}$

稻雚混合

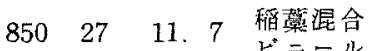

29427 11. 7 ビ

第 3 表 レンダりウエンシレージ

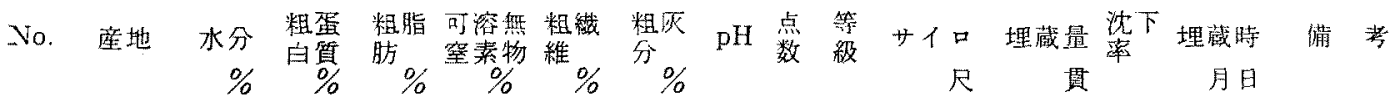

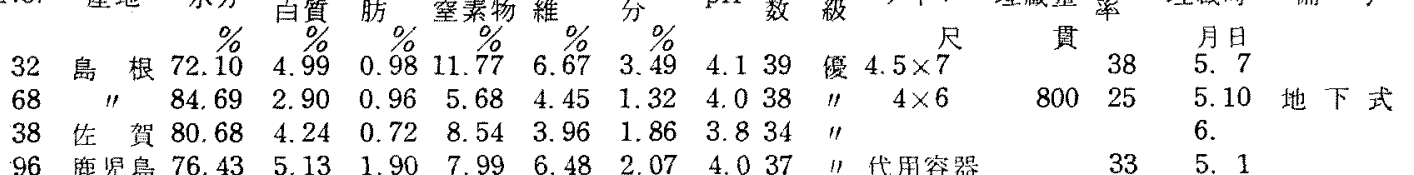

第 4 表 混合材料エンシレージ

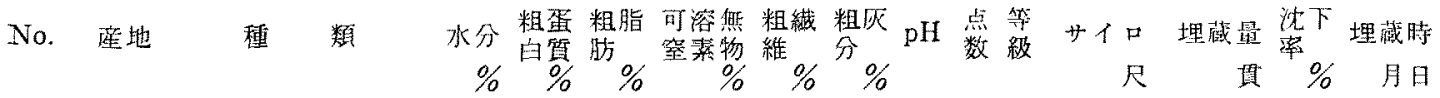

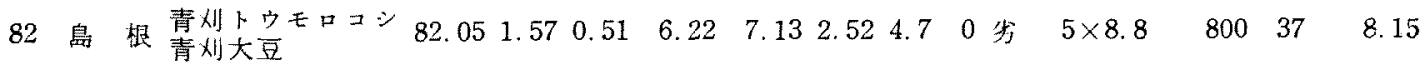

$83 \quad$ " " $\quad 78.141 .98 \quad 0.56 \quad 9.15 \quad 7.872 .304 .6 \quad 4$ 少

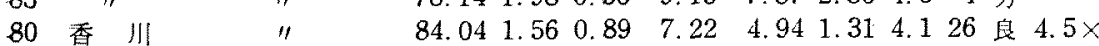

81 岛" 69

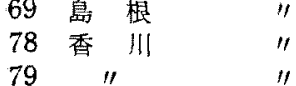

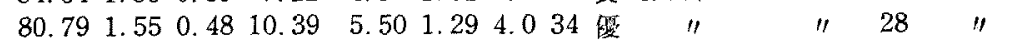

33 赧児息 "

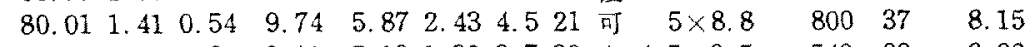

$\begin{array}{lllllllllllll}82.27 & 1.42 & 0.64 & 9.11 & 5.19 & 1.32 & 3.7 & 30 & \text { 莨 } & 4.5 \times 9.5 & 540 & 28 & 9.20\end{array}$

$\begin{array}{llllllll}81.82 & 1.23 & 0.67 & 10.04 & 4.82 & 1.42 & 3.7 & 31\end{array}$ 良

49 伦 贺 "

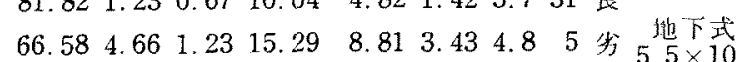

$1.300 \quad 18$ 食塩添加

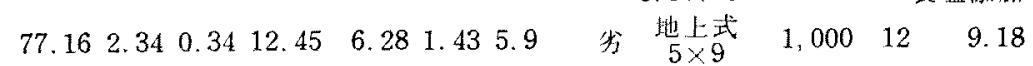

701 鹿愳島 青刘トウモモロコシ

$\begin{array}{lllllllllllll}82.21 & 1.33 & 0.36 & 8.72 & 5.66 & 1.72 & 4.0 & 23 & \text { त丁 } & 3.9 \times 8.3 & 350 & 20 & 8.6\end{array}$

$13 \quad$ 青刏トウモロコシ
10 スーダングラス

$\begin{array}{llllllllll}85.11 & 1.30 & 0.31 & 6.30 & 4.57 & 2.41 & 4.6 & 4 & \text { 少 } & 5^{2} \times 5\end{array}$

$300 \quad 10.27$

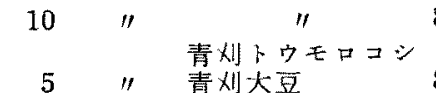

$85.53 \quad 1.01 \quad 0.40 \quad 5.44 \quad 5.47 \quad 2.15 \quad 4.320$ 䇛

$\begin{array}{lll}200 \quad 36 & 10.28\end{array}$

$5 \quad$ 青刈大豆

$81.65 \quad 1.68 \quad 0.66 \quad 8.95 \quad 5.181 .88 \quad 3.735$ 優地上式

$17 \quad 7.22$

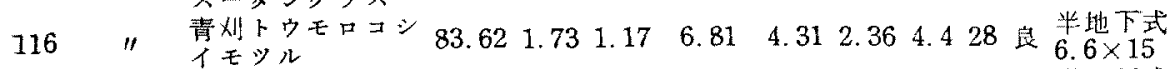

98 德島堆草

$1,500 \quad 30 \quad 11.17$

$1,000 \quad 8 \quad 5.12$ 
第 5 表 サッマイモ及びイモヌカエンシレージ

\begin{tabular}{|c|c|c|c|c|c|c|c|c|c|c|c|c|c|c|c|}
\hline No. & 尘地 & 種 & $\begin{array}{r}\text { 水分 } \\
\%\end{array}$ & 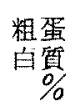 & $\begin{array}{l}\text { 粗脂 } \\
\text { 肪 } \\
\%\end{array}$ & $\begin{array}{r}\text { 可溶孟 } \\
\text { 空暴物 } \\
\% \\
\%\end{array}$ & $\begin{array}{c}\text { 粗瀻 } \\
\text { 維 } \\
\%\end{array}$ & $\begin{array}{l}\text { 粗㕄 } \\
\text { 分。 } \\
\%\end{array}$ & $\mathrm{pH}$ 数 & : 等 & $\begin{array}{r}\text { サ } \\
\text { 尺 }\end{array}$ & $\begin{array}{r}\text { 埋藏量 } \\
\text { 貫 }\end{array}$ & $\begin{array}{l}\text { 淆下 } \\
\% \\
\%\end{array}$ & \begin{tabular}{ll} 
埋藏 & \multicolumn{1}{c}{} \\
時 & \multicolumn{1}{c}{} \\
月 &
\end{tabular} & 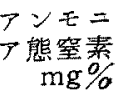 \\
\hline 31 & 麇思島 & サッマイモ & 58.02 & 1.30 & 0.45 & 38.21 & 0.90 & 1.12 & 4.140 & 優。 & $\begin{array}{l}\text { 地下式 } \\
2.7 \times 6\end{array}$ & 330 & 3 & 12.10 & \\
\hline 74 & " & ムシサッマイモ & $€ 64.57$ & 2.03 & 0.35 & 31.62 & 0.92 & 0.51 & 4.332 & 良 & 代用容器 & - & 10 & 12. 7 & 2.9 \\
\hline 28 & 覀 媛 & $\begin{array}{l}\text { イモヌカ } \\
\text { (含麦桶) }\end{array}$ & 61.09 & 3.15 & 0.93 & 29.00 & 1.64 & 4. 19 & 4.916 & 中 & $4.5 \times 8.5$ & 500 & 10 & $\begin{array}{l}11 . \\
19 \sim 20\end{array}$ & \\
\hline 117 & 熊 本 & $\begin{array}{c}\text { イモヌカ } \\
\text { (含麦粶) }\end{array}$ & 56.46 & 4.90 & 1. 40 & 33.81 & 1.56 & 1.87 & 3.634 & 雷 & & & & & 20.3 \\
\hline 88 & 展 唭 & $\left(\right.$ ( ッ⿻゚弋 ${ }^{\prime \prime}$ & 54.08 & 3.75 & 4.01 & 32.53 & 3.00 & 2.63 & 4.140 & $\prime \prime$ & $6 \times 8$ & 1,100 & 19 & 12.16 & 36.5 \\
\hline 47 & 能 本 & (イモヌカ) & 60.28 & 4.59 & 4.80 & 25.24 & 2.60 & 2.49 & 4.132 & 良 & $4 \times 8$ & 850 & 13 & 11.12 & \\
\hline 53 & " & " & 58.16 & 4. 17 & 3.93 & 28.50 & 2.25 & 2.99 & 4.332 & 11 & $\begin{array}{r}\text { 地下式 } \\
5 \times 10\end{array}$ & & 5 & $\begin{array}{l}12 . \\
5 \sim 6\end{array}$ & 44.5 \\
\hline 93 & "1 & $" 1$ & 57.97 & 4.79 & 5.28 & 24.53 & 4.95 & 2.48 & 4.040 & 曆 & & & & & \\
\hline 94 & $\prime \prime$ & $" \prime$ & 57.15 & 4.50 & 5.47 & 26.65 & 3.77 & 2.46 & 4.139 & 11 & & & & & \\
\hline 111 & $" \prime$ & $" \prime$ & 55.90 & 4.47 & 4.98 & 29.19 & 2. 69 & 2.77 & 4.039 & $\prime \prime$ & & & & & \\
\hline 167 & " & $"$ & 51.23 & 5.23 & 5.05 & 32.48 & 3.04 & 2.97 & 4. 238 & $\prime \prime$ & $4 \times 8$ & 800 & & 11.19 & 16.3 \\
\hline 170 & $" \prime$ & " & 48.50 & 5.19 & 5.34 & 35.03 & 2.68 & 3.26 & 4.238 & $\prime \prime$ & & & & & 45.2 \\
\hline 173 & " & " & 50.00 & 4.82 & 4.72 & 35.03 & 2.60 & 2.97 & 4.621 & 可 & & & & & \\
\hline 112 & $" \prime$ & 尿素 $1.2 \%$ 添加 & 11 58.04 & 6.36 & 4. 49 & 26.66 & 2.22 & 2.23 & $\begin{array}{lll}5.0 & 17\end{array}$ & 11 & $4 \times 8$ & & & 11.30 & 436.8 \\
\hline 113 & $" \prime$ & $\prime \prime$ & 59.59 & 6.35 & 3.51 & 25.94 & 2.28 & 2.33 & 4.917 & 11 & $\prime \prime$ & . & & & 354.5 \\
\hline 54 & $" \prime$ & $" 0.6 \%$ 添加 & 59.56 & 5.62 & 3.29 & 27.50 & 1.71 & 2.32 & 4. 332 & ，良 & & & & & 87.1 \\
\hline 85 & "l & $" 1 \%$ & 61.19 & 6.57 & 4.59 & 22.73 & 2.54 & 2.38 & 4. 332 & $1 t$ & 代用容器 & & & 12.11 & 234.1 \\
\hline 86 & $\prime \prime$ & $" 2 \%$ & 61.16 & 7.50 & 4.49 & 21.19 & 2.32 & 3.34 & 6.217 & 可 & " & & & 11.30 & 535.9 \\
\hline 87 & $\prime \prime$ & $" 13 \%$ & 60.50 & 8.10 & 4. 10 & 22.64 & 1.68 & 2.90 & $\begin{array}{ll}7.2 & 0\end{array}$ & 少 & "l & & & $\prime \prime$ & 877.5 \\
\hline 119 & $\prime \prime$ & $" 1.2 \%$ & 57.35 & 6.25 & 5.30 & 25.37 & 2.70 & 3.03 & 5.017 & 可 & $4 \times 8$ & & & & 263.2 \\
\hline 120 & "l & $" 1.2 \%$ & 60.67 & 7.11 & 4.88 & 22.22 & 2.50 & 2.62 & 5. 317 & $" \prime$ & $4 \times 8$ & & & & 198.5 \\
\hline 168 & $" \prime$ & $113 \%$ & 49.50 & 9.32 & 5.24 & 28.40 & 4. 47 & 3.07 & $\begin{array}{lll}7.5 & 16\end{array}$ & "' & & & & & 712.5 \\
\hline 171 & '1 & $113 \%$ & 48.00 & 8.37 & 5.27 & 32.57 & 2.70 & 3.09 & $\begin{array}{ll}7.8 & 17\end{array}$ & $\prime \prime$ & & & & & \\
\hline 127 & $" \prime$ & $113 \%$ & 50.30 & 7.39 & 5.27 & 31.78 & 2.44 & 2.82 & 7.617 & $" \prime$ & & & & & \\
\hline
\end{tabular}

第 6 表 各種エンシレージ成分 (1)

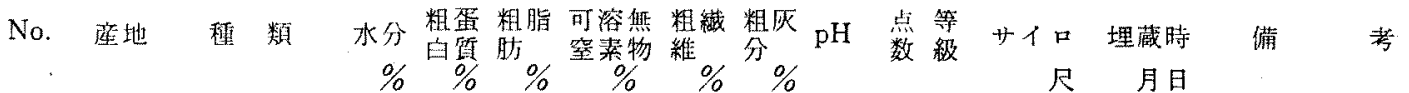

27 群焉 盗 滥 $72.424 .88 \quad 0.97 \quad 12.04 \quad 4.465 .236 .9 \quad 0$ 少

$57 " \quad$ " $\quad 78.804 .761 .307 .16 \quad 2.855 .135 .4 \quad 0$ 少半地下式

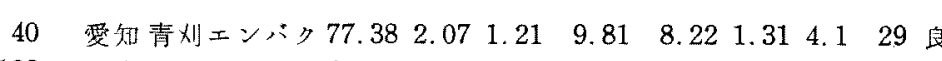

128 能本 " $\quad 62.252 .691 .3817 .3513 .772 .564 .424$ 可

$130 \quad$ " " $52.573 .81 \quad 1.2623 .3515 .143 .875 .0 \quad 8$ 少

132 " " $63.042 .641 .4515 .9013 .73 \quad 3.244 .8 \quad 15$ 中

$129 \quad$ " " $\quad 79.64 \quad 1.520 .91 \quad 8.28 \quad 8.03 \quad 1.624 .8 \quad 0$ 少

$131 \quad$ " " $\quad 79.24 \quad 1.800 .84 \quad 8.40 \quad 7.97 \quad 1.754 .2 \quad 22$ 可

$133 \quad$ " $\quad 71.652 .200 .5311 .30 \quad 9.46 \quad 4.86 \quad 6.4 \quad 12$ 中

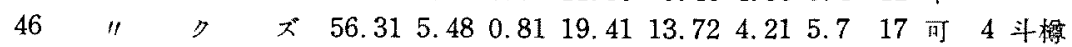

$163 \quad$ " $\quad 68.904 .060 .7311 .6311 .273 .415 .6 \quad 7$ 少 $4 \times 8$

$4 \times 10 \quad 6.10$ 沈下州 $11 \%$

5.20 廃剩部殆どなし

鞋(材料を)

"

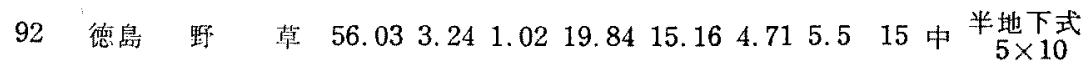

$9.17 ヒ^{*}=ー ル$ 被澓

9.12 埋戴量 1000 望

76 本熊山林雑营 $63.494 .31 \quad 0.84 \quad 16.34 \quad 11.203 .825 .2 \quad 10$ 中 $4 \times 8$

10.15 ナラ,ササ, 雄䓬

第 7 表は実鈳室にて小規模に慗造した各種材料のエンシレージの成分である. 


\begin{tabular}{|c|c|c|c|c|c|c|c|c|c|c|c|c|c|}
\hline 類 & 水分 & $\begin{array}{l}\text { 粗䵝 } \\
\text { 白篮 }\end{array}$ & $\begin{array}{l}\text { 粗脂 } \\
\text { 肪 }\end{array}$ & 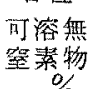 & $\begin{array}{l}\text { 粗䋐 } \\
\text { 維 }\end{array}$ & $\begin{array}{l}\text { 粗灰 } \\
\text { 分。 }\end{array}$ & $\begin{array}{l}\text { 純蛋 } \\
\text { 白贔 }\end{array}$ & $\mathrm{pH}$ & $\begin{array}{l}\text { 点 } \\
\text { 数 }\end{array}$ & $\begin{array}{l}\text { 等 } \\
\text { 粐 }\end{array}$ & 沈下 & $\begin{array}{c}\text { 整造中心 } \\
\text { 乾物攅失 }\end{array}$ & 埋藏时 \\
\hline シマイエッル & 84.62 & 2.27 & 1.23 & 6.18 & 3.30 & 2.40 & & 3.8 & 36 & 優 & 36 & $20^{\%}$ & 10.22 \\
\hline "（尿点 $1 \%$ 添加） & 79.52 & 4. 18 & 0.82 & 8.81 & 4.21 & 2.46 & & 4.0 & 40 & 17 & 21 & 2 & 11. \\
\hline 杊エン: & 78.43 & .34 & 1.98 & 5.44 & 7.42 & 2.39 & & 6.8 & 13 & 中 & & & \\
\hline$"$ & 74.73 & .03 & .86 & 10.40 & 8.71 & 3.24 & & 5.9 & 0 & 劣 & 27 & & 5. \\
\hline$卜 1 モ$ 葉 & 68.88 & 7.85 & 95 & 11.41 & 4.38 & 3.53 & 4.09 & 4.4 & 27 & 良 & 49 & 31 & 10.25 \\
\hline おおあわだちそ5 & 86.22 & 1.86 & 70 & 6.17 & 3. 42 & 1.63 & 1.45 & & & s & 46 & 33 & 5.10 \\
\hline 桑葉（秋期残葉） & 68.35 & 4.98 & .47 & 13.96 & 4.71 & 5.53 & 3.69 & 5.6 & 16 & 中 & & 12 & 10. \\
\hline 督 & 11 & 1.53 & & 16.10 & 6.42 & 5.68 & 3.31 & 5.7 & 15 & 中 & 32 & & 5.28 \\
\hline タマナ残 染 & .73 & 1.06 & 33 & 6.44 & 2.52 & 1.62 & 0.43 & 4.4 & 28 & 息 & & 13 & 6.27 \\
\hline & 89.87 & 1.3 & $\sigma^{2}$ & 4.75 & 1.91 & 1.60 & 0.58 & 4.4 & 28 & 良 & & & 6.27 \\
\hline ダイコン菱葉 & 79.77 & 4.79 & 26 & 8.10 & 3. 63 & 2.45 & 1.76 & 5.2 & 16 & 中 & & 24 & 1.11 \\
\hline ス & .29 & 4.6 & 1.71 & 7.43 & 2.81 & 3.08 & 3 & 4.7 & 17 & 可 & & 17 & 9.24 \\
\hline & 56 & 6. & $?$ & 7 & 4.49 & 9 & & 5.0 & 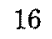 & 中 & 35 & 26 & 10.25 \\
\hline ンドウ莢 & .20 & 2. & & $1:$ & 6 & & & 3.7 & 35 & 悬 & & 25 & 5. \\
\hline ボチヤ茎藥 & 65 & 3.0 & ( & 4 & 2.61 & 0 & 1.35 & 6.1 & 17 & 可 & & 34 & 10. 7 \\
\hline ウリッル & 4.77 & 1. & 0. & 4.52 & 5.75 & 3.08 & & 6.2 & 1 & 少 & & 27 & 10.14 \\
\hline ンドウシル & 76.30 & 3.3 & 1. & 9.56 & 7.56 & 8 & 1. & 4.1 & 40 & 尉 & 28 & 20 & 5.19 \\
\hline ノラマメ荎䊾 & 81.03 & 2.86 & 0.78 & 7.56 & 6.38 & 39 & 1. & 4.5 & 25 & & & 16 & 5. 1 \\
\hline ナトイも荃 & 92.00 & 0.84 & 0. & 4.16 & 2.03 & 80 & a & 3.8 & 35 & & & 32 & 9.23 \\
\hline$"$ & 78.41 & 4.76 & 2.05 & 9.03 & 3.10 & 2.65 & 3.63 & 4.1 & 40 & I & & $f$ & $" \prime$ \\
\hline タマネギ藮(廃雃部) & 79.42 & 2.95 & 1.91 & 8.71 & 4.05 & 2.96 & 1.78 & 4.1 & 39 & $"$ & & 20 & 6.12 \\
\hline 林 イモ又カ & 65.46 & 3.87 & 7.08 & 16.06 & 4.70 & 2.83 & 2.73 & 4.4 & 27 & 良 & 24 & 9 & 7.16 \\
\hline 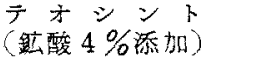 & 79.70 & 1.20 & 0.47 & 10.04 & 6.25 & 2.34 & & 3.5 & 33 & 傮 & 12 & 4 & 10.10 \\
\hline " & & 1.2 & 0.6 & 10 & 6.25 & & & 7 & & & & & \\
\hline & & 1.24 & & 9.82 & 6.07 & 2. & & 3.4 & 32 & 受 & & & \\
\hline & 8.2 & 2.24 & 1.84 & 6.92 & 8.97 & 2.19 & & 5.9 & 0 & & & 26 & 5. \\
\hline & 83.30 & 1.33 & 1.30 & 6.53 & 5.79 & 1.75 & 0.72 & 4.1 & 40 & 降 & 49 & 14 & 4.23 \\
\hline
\end{tabular}

今第 $1 \sim 5$ 表より各成分の平均値を示すと第 8 表のと㧍りである.

第 8 斌 各エンシレージ成分平均含量

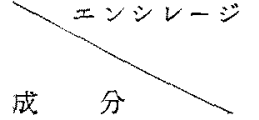

乾物

粗蛋白質

可溶敏窒素物

粗䋞維
粗分

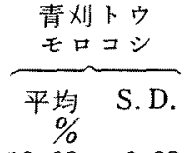

19.93

1.51

0.50

6. $23 \quad 18.87$

$0.53 \quad 2.00$
0.18

0.18

9.92

3. 69

5.98

2. 02

0.67

8.86

4.90

$0.56 \quad 2.44$

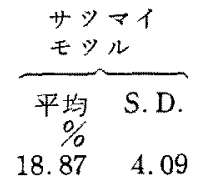

平均 S.D.

$4.09 \quad 44.47$

0.53

0. 25

4.50 $\begin{array}{ll}2.46 & 30.17\end{array}$

1. 17

0.93

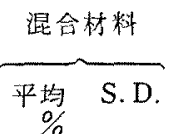

$4.25 \quad 19.49$

$0.61 \quad 1.80$

1. 53

0.62

8. 87

$6.08 \quad 1.45$

2. 12
4.30

0.88

0.27

0.65
レンゲ

毞 桨

$\%$

21.53 S.D.:

20. 18

5.41

39.20

25.30

9.91

茎葉類エンシレージの平均乾物含量は $21.95 \pm 7.95 \%$ で,Axelsson(7) の例に比較して低い，各含量别階級 の試料の分布を調查した結果は Brown ${ }^{(8)}$, Collins ${ }^{(9)}$ 等の取报ったものよりやや低いとみなすことができた。材 料の乾物含量はサイロ内に叔汁栄養素損失に極めて大きな影響をもつものであるから，少くとも25\%位迄上 昇せしめるのが望亲しい、イモヌカエンシレージの平均乾物含量は $44.5 \%$ であった。

品質の一指標となる $\mathrm{pH}$ 洒とエンシレージの水分含量との相関を检したのに，r=+0.451 $(|t|=3.848, p<$

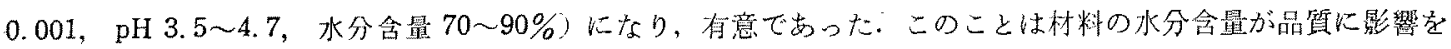
与光ることを推察させる。

エンシレージ製造に当り，酸酻熟成に伴って，沈下するものであるが（兆石の量によってもての度合は支配さ れる)，埋藏時に対するでき上りまでの沈下染は，品質と何等かの関倸がないかをみた(平抣沈下率 $24.1 \pm 9.55 \%$ ). すなわりその点数と沈下率との相関を検したが，r=ー0.074 となって有意な相関が認め得なかった．従って沈 下萃は常に品質を支配する有力な単独因子と考光ることはできない。 
次に乾物合量が大であれば，埋藏後の沈下は少いと考えられるので,その相関を求めた結果は $r=ー 0.346(p<~$ 0.01)となり，有意であった。

な叔材料に上る成分間の関係を示すと第 9 表のと就りである.

第 9 表 材料に上る成分含量の比較（乾物対）

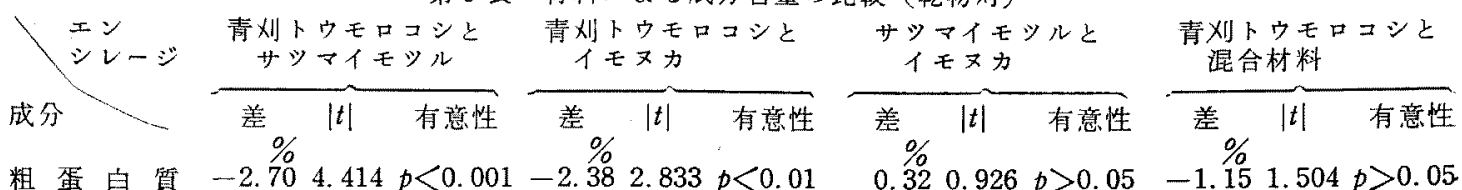
$\begin{array}{cccccccccccccc}\text { 粗 蛋 } \text { 白 } & \text { 質 } & -2.70 & 4.414 & p<0.001 & -2.38 & 2.833 & p<0.01 & 0.32 & 0.926 & p>0.05 & -1.15 & 1.504 & p>0.05 \\ \text { 粗 } \text { 脂 } & \text { 肪 } & -0.93 & 3.245 & p<0.01 & -6.82 & 9.490 & p<0.001 & -5.89 & 7.226 & p<0.001 & -0.57 & 1.503 & p>0.05\end{array}$ 可浚製空素物 $\quad 2.400 .962 p>0.05-18.305 .771 p<0.001-20.708 .971 p<0.001-3.941 .346 p>0.05$. 粗 維 $4.042 .594 \quad p<0.02 \quad 23.6812 .153 p<0.001 \quad 19.6415 .060 p<0.001 \quad-1.390 .775 p>0.05$. 粗灭 分 $-2.812 .983 p<0.01 \quad 3.823 .448 p<0.01 \quad 6.636 .419 p<0.001 \quad-0.720 .672 p>0.05$

この結果は，青刚トウモロコシ，サッマイモッル，イモヌカエンシレージとの関倸は，通常考齐られていると こらと一致して揖り，青刈トウモロコシ，混合材料ェンシレージの比較では有意差が認められなかった。

更に品質による“侵良”，“可中少”の二群に分ち，これらの中に含まれる陚料の成分を比較した結果は第 10 㤗のと拉りである。

第 10 表 品質による成分含量の此較 (茎葉類晞物対)

品筫群

\begin{tabular}{|c|c|c|c|c|c|c|c|}
\hline \multirow[t]{3}{*}{ (假 } & \multirow[t]{3}{*}{ 中 } & \multirow[t]{3}{*}{$\begin{array}{l}\text { 良 } \\
\text { 少) }\end{array}$} & $\begin{array}{r}\text { 平均 } \\
\% \\
20.42 \\
18.00\end{array}$ & $\begin{array}{l}\text { S. D. } \\
\begin{array}{l}4.49 \\
3.81\end{array}\end{array}$ & $\begin{array}{l}\text { 差 } \\
2.42\end{array}$ & 2.210 & 有憲性 \\
\hline & & & \multicolumn{5}{|c|}{ 粗 㵶 維 含 量 } \\
\hline & & & $\begin{array}{r}\text { 平均 } \\
\%\end{array}$ & S. D. & 差 & $|t|$ & 有意性 \\
\hline （㑑 & 中 & 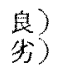 & $\begin{array}{l}27.25 \\
34.50\end{array}$ & $\begin{array}{l}5.17 \\
6.03\end{array}$ & -7.25 & 5.171 & o \\
\hline
\end{tabular}

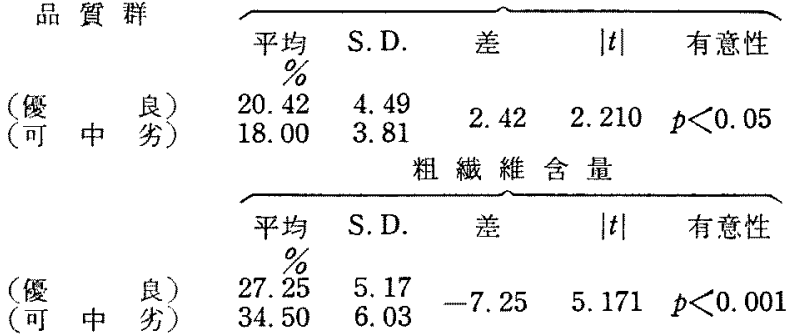

乾物 含 量
可溶無窒丵物含量

平均 S.D. 差 $|t|$ 有意性

$\begin{array}{lllll}49.77 & 7.34 & 7.24 & 3.113 & p<0.01\end{array}$ 粗灰分含量

$\begin{array}{rcccc}\begin{array}{r}\text { 平均 } \\ \%\end{array} & \text { S.D. } & \text { 差 } & |t| & \text { 有意性 } \\ 10.11 & 3.05 & & & \\ 13.10 & 3.66 & -2.99 & 3.576 & p<0.001\end{array}$

この絬果は，品質良好な場合を，それ上りも少る場合に比較すると，乾物，可溶無窒素物含量が多く, 粗維維, 粗灰分含量の少いことを示している.このことは乾物, 酸酵性炭水化物含量の多賽が, エンシレージの品質を支 配する因子となることを証するものである。また粗蛋白質含量少く，粗脂肪含量は多い傾向にあったが，更めて 检討する.

\section{III. 総 括}

（1）全国より集わたエンシレージ試料，実験室製造各種エンシレージの一般分析結果及び品質を示した.

(2) 茥葉類エンシレージの平妁漧物含量は $21.95 \%$ て，一般に水分が多い㑯向にあることが知られた。

（3）イモヌカエンシレージ類は一般に品貿が良好でかったが，尿素添加 $2 \%$ 以上のbのはアンモニア含量が 多く，品質が少った.

（4）品質と埋蔵後に扎けるサイ口内の材料沈下率との間には，有意な相関は見出されなかったが，乾物含量 と沈下慗との間には栖意な偵の相関が見出された（ $r=-0.346 ， p<0.01)$.

(5) 材料の差による成分含量の比较を示した。

（6）品質の一指摽と考えられるェンシレージの pH 何と，水分含量との間には，有意な正の相関が認められ た $(r=+0.451, p<0.001)$.

（7）品質傮良に属する試料と，これより少るものの試料との成分含昷を比較した結果，前者加乾物，可溶無

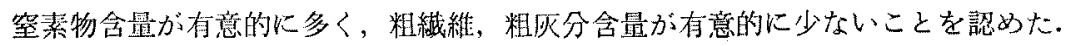

本実験を施行するに当り，多大の御援助並びに御助言を睗った九大教授崔田久敬博上，名大教授斎藤道雄博士 に感謝の意をあらわし，また分析上多大の協力をいたたいた鹿大教育学部調理科学研笔空林みき子助教授，公立

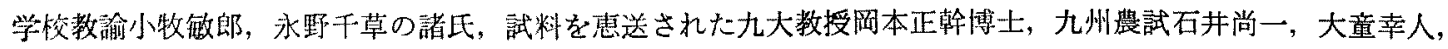




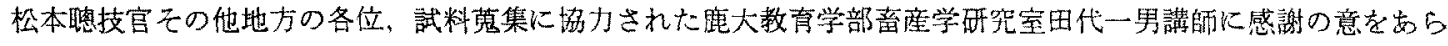
わす。
(1) 筫藤 浩： 本誌, $30,259 \sim 263$ (1956).

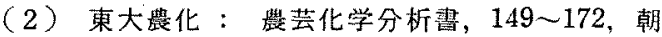
(6) K. Gneist : [E. Brümmer. zit. Bieder- manns Zbt. Tievern., 12, 98, 1940].
倉甾店 (1948).
（3）河田竜夫： 統計学概諭， $90 ， 106 \sim 7$, 文耀 社 (1950).
(7) J. Axelsson : Kgl. Lantbruks-Högskol. Ann., 18, 7 20 (1951).
(4) J.F. Kenney: Mathematics of Statistics, 184 6 (1939).
（5）鍋島信太郎他： 数理統部学, $57 \sim 58$, 池田 書店 (1950)。
(8) W. O. Brown : British Grassland Soc., 5(3), 225 235 (1950).
(9) F. C. Collins et al. : Agriculture, J. Minist. Agr. 59, 367 71 (1952).

\begin{tabular}{|c|c|c|}
\hline \multirow[t]{10}{*}{ [附記] } & 第 1 報 正誤表 & (本誌 $30,259 \sim 263(1956)$ ) \\
\hline & 頁 & 位 \\
\hline & 261 & 上加ら 2 行目 \\
\hline & $" \prime$ & Table 5, 下加 51 行目 \\
\hline & $" \prime$ & Table 6, 下加52 行目 \\
\hline & $"$ & 下から2行目 \\
\hline & 263 & Table 10,5行目, $\mathrm{pH}$ 欄 \\
\hline & $" \prime$ & 追記，下から1行目 \\
\hline & $" \prime$ & 文献 (8) \\
\hline & " & $\prime \prime(10)$ \\
\hline
\end{tabular}

$\begin{array}{cl}\text { 譟 } & \text { 正 } \\ 19.92 & 12.92 \\ 34.43 & 35.43 \\ 14.87 & 14.89 \\ \text { トレンサイロ } & \text { トレンチサイロ } \\ p<0.05 & p>0.05 \\ \text { 本学部教授 } & \text { 本学教授 } \\ 89 \sim 9 & 98 \\ 10 & 90\end{array}$

清 酒 用 麴 菌 $の$ 研 究 (第 4 報)*

清酒の醸造試験について

村上 英也（国税庁䤑造試験所）

昭和 32 年 6 月 15 日受理

緒 言

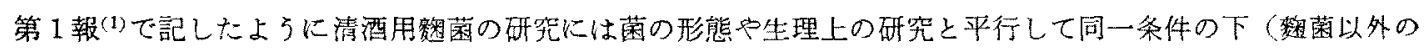
諸条件の相違を無視し得るような同じ条件の下）に実地の酸造試験を行５必要があり，これが最も合理的な研究

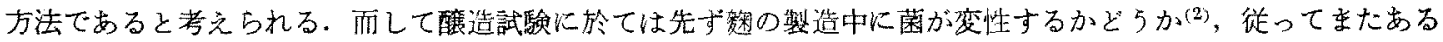

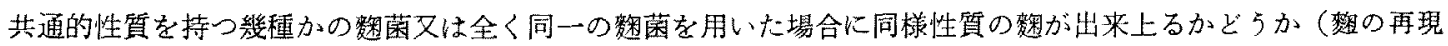

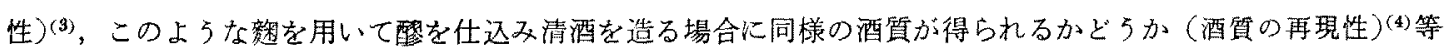

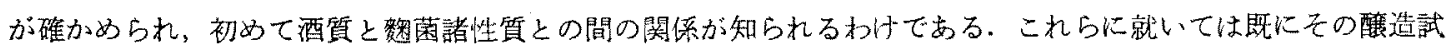

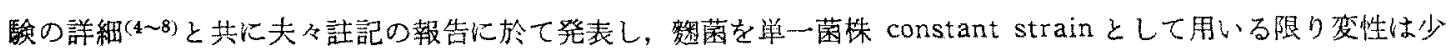
く，笣や酯及び酒質にある程度再現性のあることを明かにしたので，今回はこれらを総括し，未発表の分と共に 報告する.

\section{実駼 $\odot$ 部}

1. 菌株の選択同一菌株を用いて幾回も試酰を行らか，又は菌株は異るが或る共通の性質を持ついくつか

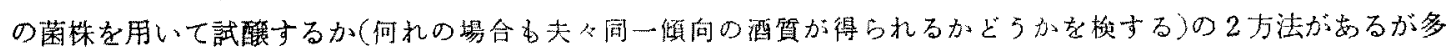
数の菌種を取报了関釈上主として後者の方法により，特别の場合前者によることとし，23個の菌群の中から夫ネ の群の No. にて示される代表菌株 11 株を用いた，即ちNo. 18，23，25，40,69，70，101，127，138，139，143である. 但しこの中 No. 18 は変異前の strain を用いて試酸したもので, その諸性質はすべて变異後のものである。

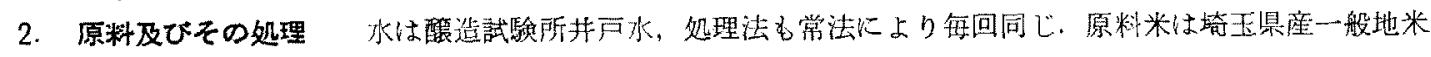

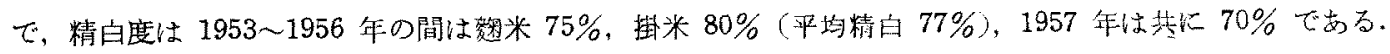

* Studies on the Aspergilli for Saké Brewing. Part IV. On the Brewing of Saké. By Hideya MURAKAMI (Brewing Experiment Station, Tax Administration Agency) 